Ethiopian Journal of Environmental Studies \& Management 9(5): 545 - 553, 2016.

ISSN:1998-0507

doi: http://dx.doi.org/10.4314/ejesm.v9i5.2

Submitted: February 03, 2016

Accepted: August 30, 2016

\title{
COMPULSORY LAND ACQUISITION AND COMPENSATION IN NIGERIA: COASTAL COMMUNAL PERCEPTION
}

\author{
*IGE, V.0., ${ }^{1}$ AKINTOMIDE, A.J. ${ }^{2}$ AND ADEOLA, T.0. ${ }^{2}$ \\ ${ }^{1}$ Department of Estate Management, Federal University of Technology Akure \\ P.M.B 704, Akure, Ondo State, Nigeria \\ ${ }^{2}$ Department of Estate Management, Rufus Giwa Polytechnic Owo, Nigeria \\ P.M.B 1019, Owo, Ondo State, Nigeria
}

\begin{abstract}
The extent of manageable displacement is one of the biggest problems faced today in coastal regions during compulsory land acquisition. Coastal communities are usually extremely affected due to scarcity of land. The resultant effect is often flawed mega projects, loss of lives, mass resistance and sometimes violent protests. It is upon this premise that this paper investigates the issue by exploring the views of riverine communities in Ondo State, Nigeria towards compulsory acquisition and compensation. To achieve this, six coastal communities (Igbokoda, Ugbonla, Igbegunrin, Mahin, Mahintedo and Aiyetoro) were selected. Questionnaires were randomly administered on One hundred and eighty (180) communal in the selected areas out of which One hundred and twenty (120) were retrieved and analysed using qualitative descriptive statistics. The result of the analysis revealed "cessation of income generating activities" (traditional jobs and productive skills), "decline in living standard", and "weakened community institutions and social networks" as major perspectives of coastal communal to land acquisition in the study area. Coastal communal expectations from the acquiring authority includes "allocation of sufficient time and resources for community consultation over land acquisition and compensation issues", "reduction in physical displacement" and "employment assistance for the land-loss communities' labor force market". The study recommends adequate allocation of time and resources for community consultation over land and compensation issues, as the majority of coastal population greatly relied on land as source of livelihood.
\end{abstract}

Key Words: Coastal communal, Perception, Compulsory land acquisition, Compensation

\section{Introduction}

Land is part of the culture of a nation and at both national and individual level people are prepared to fight to defend it. It is a highly sensitive resource as people depend on it for survival and usually place high value on it as source for several uses and for different opportunity costs that they might incur from their use. In view of this, different perspectives 
arises when land are compulsorily acquired by the government (Noel, 1998). Compulsory land acquisition is an essential tool of government in acquiring private property to provide public facilities for comfort of the citizens (Food and Agricultural Organization, 2008). However, according to Larbi (2008), it usually comes with some sort of discomforts, as it often results in either displacing people economically or physically. In either way, compensation of affected persons is required (Deininger, 2003; Okere, 2003). Nevertheless, expropriated owners more often than not thwart government efforts to put land to the intended use (Larbi, 2008). Odudu (2003); Omirin and Famuyiwa (2011) observed that communities appear not to be thoroughly satisfied because the Land Use Act 1990 seems not to have directly addressed the issue of compensation for the land itself. This contributes to community dissatisfaction and disputes over land acquisition.

Coastal communities are unique, particularly because of the scarcity of land and as such many people are rendered homeless during acquisition. This further put them under considerable strain. As a consequence, compulsory land acquisition in the coastal communities often flaw mega projects and usually the root cause of delays, cost overruns, loss of lives, mass resistance and sometimes violent protests. At times acquiring agents or expatriates are abducted by the coastal communities as there is usually diversity of opinions within the communities. According to Observer Research Foundation (2010), billion dollars' worth of investments are getting endangered and a number of projects are being affected during the process of land acquisition as violence are common phenomenon in many compulsory land acquisitions, predominantly in the riverine areas.

One illustrative instance is the resistance to compulsory acquisition procedure for a private oil refinery in the riverine area of Ondo State, Nigeria in 2013. Opposition to compulsory acquisition could, according to DenyerGreen (2005) restrain acquisition power and therefore jeopardize public interests. Hence, there is the problem of how to genuinely sensitize to the feelings of the affected community. As it is not usually easy for the acquired authority to handle the emotional upheaval associated to being displaced from a locality that has been people's homeland for generations, as it requires an altruistic approach (World Bank, 2004).

Though, a number of studies like Food and Agricultural Organization (2008); Ojikutu et al. (2012) have shown that economic growth is associated with compulsory land acquisition, one continued to wonder why it is more often than not restricted. Even if compulsory land acquisition has no direct benefit in terms of cash in the short run, it has subsidiary benefit which comes over the years (Grover et al., 1999; Regulatory Impact Statement, 2010).

Previous experience has made people to resist and be apprehensive of compulsory land acquisition, particularly in the coastal communities. Land acquisition for mega projects is hence a problem both for government as well as for community whose land is being acquired, yet there must be development. 
If coastal communities are to continue with their, controversies, bad blood, skirmishes, violence and project delay there might not be tangible development (Observation Research Foundation, 2010). Up till now, nothing concrete seems to be happening about the whole situation; as causes of the compulsory land acquisition problems in coastal area, at whose expense and at what cost has not been seriously considered. Rather, the use of overt coercion and violence during the process of land acquisition are a common phenomenon in coastal areas. Therefore, rendering the voiceless community that is being dispossessed impoverished.

Once their lifestyle and livelihood is shattered, they are usually left with nothing. Little wonder while mass protests against compulsory land acquisition have become the norm (Ghatak, and Mookherjee, 2011; German et al., 2011). This must be addressed to reduce tension between expropriated communities, acquiring authorities, investors and the government. Policy proposal is hence required to deal with the outstanding issues of compulsory acquisition in riverine areas to make proposals that will guide future compulsory acquisitions.

The above backdrop has thus given rise to this study which aims at investigating the issue by exploring the views and perceptions of riverine communities toward compulsory acquisition of their traditional lands. This will provide first-hand facts on the feelings, expectations and hopes of coastal communities when they have to give away their lands for the sake of development. This will consequently influence formulation of policies for managing compulsory land acquisition efficiently in seaside communities and reduce associated tension between the acquiring authority, investors, expatriates and the communities.

\section{Study Area}

The selected study areas namely, Igbokoda, Ugbonla, Igbegunrin, Mahin, Mahintedo and Aiyetoro are in Ilaje Local Government Area of Ondo State, Nigeria. It lies within $5^{\circ} 50^{\prime}, 6^{\circ} 10^{\prime} \mathrm{N}$ and $4^{\circ} 30^{\prime} 5^{\circ} 10^{\prime} \mathrm{E}$ with a total land area of 2,300 square kilometres. It is bounded in the North by Okitipupa Local Government, in the East by Ese-Odo Local Government, in the West by Ogun State and in the South by Atlantic Ocean. According to the 2006 National Population Commission, the population of the settlement is 290,615. Mahin and Ugbo are the two dominant kingdoms in the region, while other minor kingdoms include; Aheriand Etikan, Igbokoda, Ode-Ugbo, Ugbonla, Ayetoro, OdeMahin and Ode-Etikan. The Ilajes are the major tribes while fishing is the main occupation of the people. The climatic condition in the coastal line of Ondo State follows the pattern of SouthWestern Nigeria where the climate is influenced mainly by the rain-bearing southwest monsoon winds from the ocean and dry Northwest winds from the Sahara Desert. There are two distinct seasons, the rainy and dry seasons. The riverine area of Ondo State is well endowed with high rainfall of about $2032 \mathrm{~mm}$ with an atmospheric temperature ranging between $28^{\circ} \mathrm{C}$ and $31^{\circ} \mathrm{C}$ and a mean annual relative humidity of about 30 per cent. The study area is as shown in figure 1. 


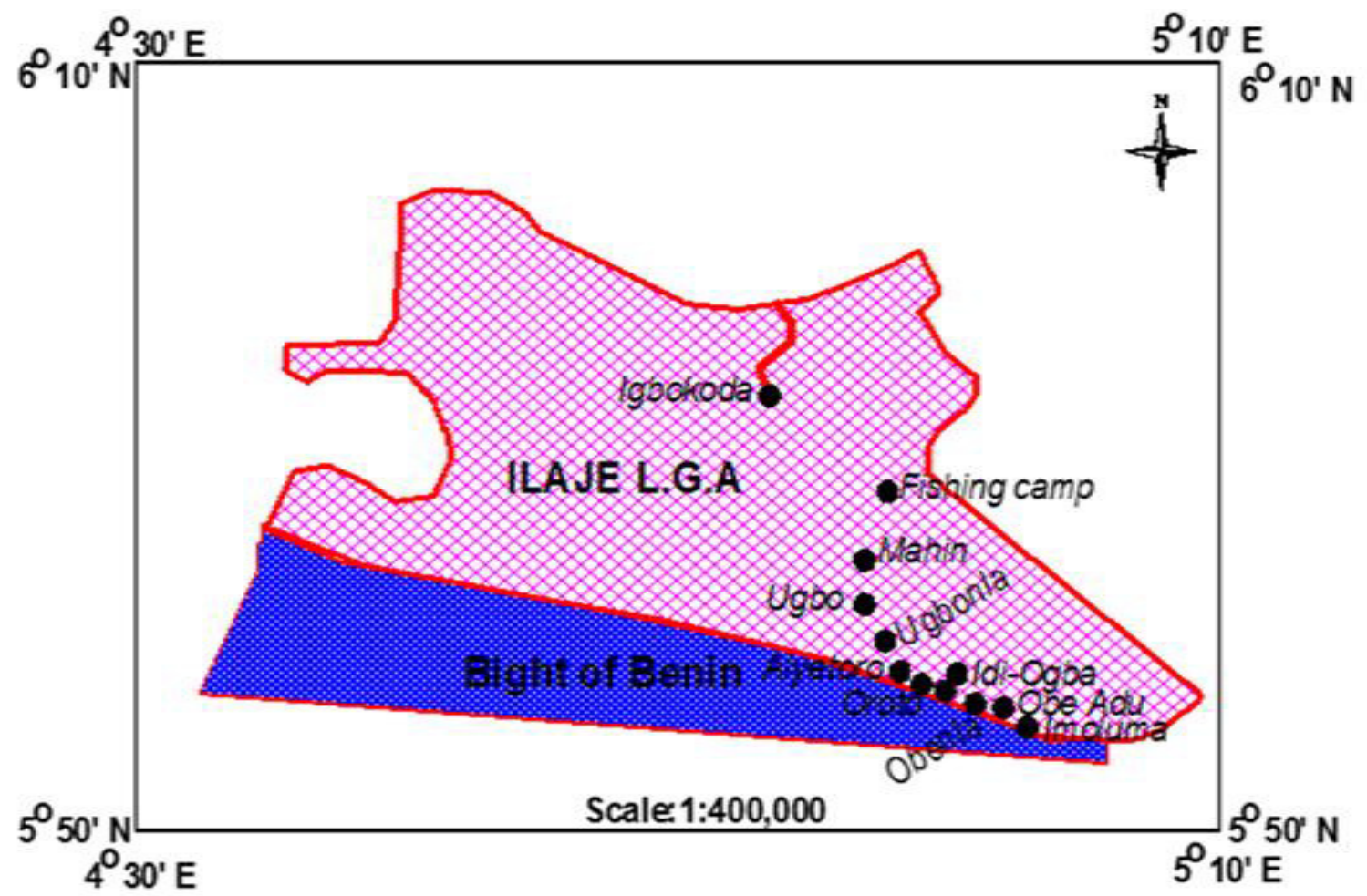

Figure 1: Map of the coastal Area of Ondo State, Nigeria.

Source: Bolarinwa, Fasakin and Fagbenro (2015)

\section{Methodology}

The study adopted cross-sectional survey design. Six (6) riverine communities in Ondo State, Nigeria namely, Igbokoda, Ugbonla, Igbegunrin, Mahin, Mahintedo and Aiyetoro were selected for the study. Study areas were selected based on their commendation from the Ondo State Land Records Bureau, due to previous experience of compulsory land acquisition and compensation in the areas. Questionnaires were randomly administered through the resident area lands officer using snowball sampling technique. One hundred and eighty (180) questionnaires were administered on coastal communal in the selected areas out of which One hundred and twenty (120) were retrieved. Respondents include elderly settlers in the communities, family heads, chiefs and community leaders. They were guided in filling the questionnaires by the resident's area lands officer and research assistant where it is required. The study used descriptive statistical tools (frequency tables, weighted mean score and relative importance index (RII)) in analyzing the data collected from the respondents. 


\section{Results}

Table 1: Background of the Respondents

\begin{tabular}{|c|c|c|}
\hline Characteristics & Frequency & Percentage \%) \\
\hline \multicolumn{3}{|l|}{ Gender } \\
\hline Male & 98 & 81.7 \\
\hline Female & 22 & 18.3 \\
\hline \multicolumn{3}{|l|}{ Maritalstatus } \\
\hline Single & 8 & 6.7 \\
\hline Married & 100 & 83.3 \\
\hline Widowed & 12 & 10.0 \\
\hline \multicolumn{3}{|l|}{ Age } \\
\hline $20-30$ years & 15 & 12.5 \\
\hline $31-40$ years & 29 & 24.2 \\
\hline $41-50$ years & 49 & 40.8 \\
\hline Above 50 years & 27 & 22.5 \\
\hline \multicolumn{3}{|l|}{ Economic activity } \\
\hline Farming & 18 & 15 \\
\hline Fishing & 45 & 37.5 \\
\hline Self-employed & 36 & 30 \\
\hline Civil servant & 21 & 17.5 \\
\hline \multicolumn{3}{|c|}{ Number of family members } \\
\hline $1-5$ & 8 & 6.6 \\
\hline $6-10$ & 65 & 54.2 \\
\hline $10-13$ & 38 & 31.7 \\
\hline Greater than 14 & 9 & 7.5 \\
\hline \multicolumn{3}{|l|}{ Education level } \\
\hline No Education & 10 & 8.3 \\
\hline Primary & 36 & 30.0 \\
\hline Secondary & 43 & 35.8 \\
\hline Tertiary & 31 & 25.8 \\
\hline \multicolumn{3}{|l|}{ Income } \\
\hline BelowN20,000 & 79 & 65.8 \\
\hline N20,000-N40,000 & 15 & 12.5 \\
\hline N50,000-N70,000 & 14 & 11.7 \\
\hline N80,000 and Above & 12 & 10.0 \\
\hline
\end{tabular}

Fishing $(37.5 \%)$ is the major occupation in the study area. This is enhanced by about $75 \%$ of the area being riverine and easy access to sea. While only about $15 \%, 30 \%$ and $17.5 \%$ of the respondents engaged in farming, selfemployment and civil service respectively. The extent of economic change is very limited, emphasizing the paramount importance of land as a source of livelihood and a vital asset. The importance of land is underscored by the widespread land scarcity. Information gathered on respondents' marital status indicates that majority $(83.3 \%)$ of the respondents are married. This may have implication on their livelihood when their properties are acquired. The age distribution of majority (40.8\%) of respondents' ranged from 41 to 50years, 
$24.2 \%$ falling between 31 and 40 years, $22.5 \%$ are more than 50 years old, while the remaining $12.5 \%$ of the respondents are between the age of 20 and 30years. This is an indication that majority of the respondents are middleaged and economically active. Thus their ability to go about their daily activities in order to earn income with which they cater for their family basic needs may be interrupted by compulsory land acquisition. The household size of the respondents ranged from 2-13; however, the average family size of the respondents is 3 . The study also observed a greater percentage of the size of households of 6-10 persons (54.2\%) is very ideal in the study areas context. The impact of large family size is such that it reduces the per capita expenditure of the family thereby aggravating their conditions when their landed properties and source of livelihoods are acquired. It is also observed that majority (91.7\%) of the respondents are literate. A significant proportion $(90.0 \%)$ of the respondents earn below $\$ 80,000.00$ annually.

Table 2: Coastal Communal Perception of Compulsory Land Acquisition and Compensation

\begin{tabular}{lll}
\hline S/N & Perceptions & RII \\
\hline 1. & It is disruptive to communities whose land is acquired & 0.723 \\
2. & Breach of rights and customs & 0.542 \\
3. & Short acquisition notice & 0.758 \\
4. & Compensation is delayed and insufficient to replace assets & 0.752 \\
5. & Cessation of income generating activities (traditional jobs and productive & 0.917 \\
& skills) & 0.895 \\
6. & Imposition of high social costs & 0.887 \\
7. & Negative impact on life & 0.908 \\
8. & Lack of resettlement scheme & 0.892 \\
9. & Psychological imbalance & 0.895 \\
10. & Deprive communities of important religious or cultural sites & 0.910 \\
11. & Weakened community institutions and social networks & 0.915 \\
12. & Decline in living standard & 0.898 \\
13. & Loss of goodwill and related benefits which cannot be compensated for & 0.895 \\
14. & Abuse of compulsory acquisition power & 0.880 \\
15. & Land provided as compensation in resettlement schemes may have poorer \\
& quality soils, lack infrastructure, water and forest resources that existed in the & \\
\hline & original location & \\
\hline
\end{tabular}

Table 2 shows the general ranking of the perception of coastal communal of compulsory land acquisition and Compensation. Analysis of the respondents' perspectives indicate that cessation of income generating activities' (traditional jobs and productive skills) is the most important among the perception of respondents. This was evident from its relative importance index (RII) of 0.917 . Followed by 'decline in living standard' with a relative importance index of 0.915 , while 'breach of rights and customs' with a relative importance index of 0.542 ranked least of the respondents perceptions. Cernea and Christopher 
(2000), World Bank (2007), Wallace (2009), noted that displacement as a consequence of compulsory land acquisition may cause severe long-term hardship and impoverishment which in turn creates certain psychological torture and negative impacts on the livelihood and income of communities.

Table 3: Coastal Communal views of the advantage of Compulsory Land Acquisition and Compensation

\begin{tabular}{lll}
\hline S/N & Advantages & Mean \\
\hline 1. & Creation of economic growth and jobs & 4.542 \\
2. & It allows government to improveits delivery of public services & 4.508 \\
3. & It promotes agricultural and rural development & 4.475 \\
4. & Enhancement of benefits to the wider community & 4.475 \\
5. & Social and economic development & 4.467 \\
6. & Protection of the natural environment & 3.758 \\
\hline
\end{tabular}

As shown in Table 3, the main benefits of compulsory acquisition from the respondents' point of view were "creation of economic growth and jobs (4.542)' and 'giving room for government to improve public services delivery' (4.508). The table also indicates other advantages, which are: 'promotion of agriculture and rural development' (4.475), 'enhancement of benefits to the wider community' (4.475), 'social and economic development' (4.467), and 'protection of the natural environment' (3.758).

Table 4: Coastal Communal expectations from the Acquiring authority on Compulsory Land Acquisition and Compensation

\begin{tabular}{|c|c|c|c|}
\hline $\mathrm{S} / \mathrm{N}$ & Coastal Communal Expectations & Mean score & $\begin{array}{l}\text { Ranking of } \\
\text { factors }\end{array}$ \\
\hline 1. & $\begin{array}{l}\text { Allocation of sufficient time and resources for community } \\
\text { consultation over land acquisition and compensation issues }\end{array}$ & 4.542 & $1^{\text {st }}$ \\
\hline 2. & Circumvention or reduced physical displacement & 4.475 & $2^{\text {nd }}$ \\
\hline 3. & Availability of expert advice during the acquisition process & 4.575 & $2^{\text {nd }}$ \\
\hline 4. & $\begin{array}{l}\text { Employment assistance for the land-loss communities labor } \\
\text { force market }\end{array}$ & 4.475 & $2^{\text {nd }}$ \\
\hline 5. & $\begin{array}{l}\text { Adequate consideration to the land-loss communities' } \\
\text { livelihood risk, unemployment risk, and impoverishment risk }\end{array}$ & 3.758 & $5^{\text {th }}$ \\
\hline 6. & Good communication and involvement of communities & 3.717 & $6^{\text {th }}$ \\
\hline 7. & Required entitlement to the displaced communities & 3.092 & $7^{\text {th }}$ \\
\hline 8. & Prompt and adequate compensation & 2.325 & $8^{\text {th }}$ \\
\hline 9. & Resettlement assistance to Physically displaced communities & 1.583 & $9^{\text {th }}$ \\
\hline 10. & $\begin{array}{l}\text { Meaningful socialization and consultation with affected } \\
\text { communities about the project and its impact }\end{array}$ & 1.392 & $10^{\text {th }}$ \\
\hline
\end{tabular}

Table 4 shows the general ranking of coastal communal expectations from the Acquiring authority on Compulsory Land Acquisition and Compensation. "allocation of sufficient time and resources for community consultation over land acquisition and compensation issues", as shown by the mean value 
of4.542 was the utmost expectation of respondents from the acquiring authorities. "Employment assistance for the land-loss communities' labor force market" (4.475), "circumvention or reduced physical displacement" (4.475), and "availability of expert advice during the acquisition process" (4.575).The lowest score on the listed expectations was "meaningful socialization and consultation with affected communities about the project and its impact" (1.392). The study is therefore in consonance with the findings of China Land Surveying and Planning Institute (2005) and Food and Agricultural Organization (2008).

\section{Recommendations and Conclusion}

This paper has attempted to establish coastal communal perception of Compulsory Land Acquisition and Compensation so as to make reasonable policy improvements in providing guidance for current policy thinking, planning and future acquisition projects. Distortion and misunderstandings around the circumstances of land acquisitions in riverine areas can be circumvented with widespread consultation. In that the problems of acquisition are more than just a matter of law and valuation. It involves justice between society and man. Adequate time and resources must be allocated for community consultation over land and compensation issues. As the majority of coastal population are greatly reliant on land as source of livelihood. Therefore, dialogue with the key stakeholders will reduce the tension between expropriated communities and the government.

\section{Acknowledgments}

We would like to thank the Area Lands officer and other research assistants who participated in questionnaire administration and for the valuable advice and information provided during the study. Effort of Dr. (Mrs) R. A. Oladapo who supervised the earlier version of this study on "claimants' perception of compulsory land acquisition and compensation in Ondo State, Nigeria" is greatly appreciated.

\section{References}

Bolarinwa, J., Fasakin, E. and Fagbenro A. (2015). Species Composition and Diversity of the Coastal Waters of Ondo State, Nigeria. International Journal of Research in Agriculture and Forestry, 2(3): 51-58.

Cernea, M. and Christopher, M. (eds). (2000). Risks and Reconstruction. Experience of Resettles and Refugees. Washington, The World Bank.

China Land Surveying and Planning Institute (2005).Asset Valuation in Land Acquisition and Compensation. PRC Thematic Report No. 2.

Deininger, K. (2003). Land policies for growth and poverty reduction. Washington DC, The World Bank/Oxford.

Denyer-Green, B. (2005). Compulsory Purchase and Compensation. The Eighth Edition, Estate Gazette, London.

FAO (2008). Compulsory Acquisition of Land and Compensation. FAO Land Tenure Studies No.10. Rome. Retrieved on 7th June, 2011, from: http://www.fao.org 
German, L., Schoneveld, G. and Mwangi, E. (2011). Contemporary processes of large-scale land acquisition by investors: case studies from subSaharan Africa. Occasional Paper 68. CIFOR, Bogor, Indonesia.

Ghatak, M. and Mookherjee, D. (2011): "Land Acquisition for Industrialization and Compensation of Displaced Farmers", WIDER Working Paper, 35.

Grover, R., Mikhail, S. and Zlatina, Y. (1999). The Development of Compulsory Purchase and Compensation in the Transitional Economies of Central Europe. Paper presented at the RICS Research Conference. The Cutting Edge, Cambridge, September 6-7.

Larbi, W. O. (2008). Compulsory Land Acquisition and Compensation in Ghana: Searching for Alternative Policies and Strategies. FIG/FAO/CNG International Seminar on State and Public Sector Land Management, Verona, Italy, September 9th 10 th.

Noel, P.G. (1998). Property Theory, Property Rights, and Land Beliefs: Views of New York State Wetlands Owners and Permit Applicants about Land Ownership and Wetlands Regulations. MSc. Thesis, Faculty of the Graduate School of Cornell University.

Observer Research Foundation (2010). Mega Project Development: Issues in Land Acquisition. Edited proceedings of a seminar organised by the Centre for Politics and Governance. New Delhi Observer Research Foundation, (1)
5.Retrieved on November 11, 2011, from:www.orfonline.org.

Odudu, W.O (2003). Standard for compensation valuation and claims in both private and public sectors in Otegbulu A.C. (ed). Guidelines and standards for valuation practice, Lagos, Chuzy tech resources Ltd.

Ojikutu, O., Bennett, R. and Groenendijk, L. (2012). An assessment of land acquisition in Nigeria. Being a paper presented at FIG Working Week, Rome, Italy, 6-10 May, 1-10.

Okere, G.T. (2003). The Role of the Estate Surveyors and Valuers in Compulsory Land Acquisition and Compensation in Nigeria.A paper presented at NIESV Anambra State Branch C.P.D Seminar, Awka.

Omirin, M. and Famuyiwa, F. (2011). Infrastructure Provision and Private Lands Acquisition Grievances: Social Benefits and Private Costs. Journal of Sustainable Development, (4)6. Retrieved from: http://dx.doi.org

Regulatory Impact Statement (2010). Land Acquisition and Compensation Regulations. Civil Law Policy Department of Justice, Melbourne, Victoria

Wallace, J. (2009). Land Acquisition in Developing Economies. 7th FIG Regional Conference on Land Governance and the Environment, Hanoi, Vietnam, 19-22 October.

World Bank (2004). Involuntary Resettlement Sourcebook. World Bank. www.worldbank.org

World Bank (2007). Operational policies on involuntary resettlement. www.worldbank.org 